\title{
Evaluation of Antioxidant and Antimicrobial Activity of Ficus Carica Leaves: an In Vitro Approach
}

\author{
Javed Ahmad ${ }^{1 *}$, Iffat khan², Salman Khan² and Danish Iqbal ${ }^{2}$ \\ ${ }^{1}$ Department of Biochemical Engineering and Food Technology, Harcourt Butler Technological Institute (HBTI), Kanpur, India \\ ${ }^{2}$ Department of Biotechnology, Integral University, Lucknow, India
}

\begin{abstract}
Ficus carica L. (fig) belongs to the mulberry tree (Moraceae) which is one of the oldest fruits in the world. It is used in our traditional system of medicine for healing various diseases. In a continuous bid to explore new biocompatible antioxidant and antimicrobial with the least associated side-effects Ficus carica were tested against pathogenic microorganisms; S. epidermidis, K. Pneumoniae, B. Subtilis, E. aerogens, and B. cereus. The methanol extracts were prepared and screened for in-vitro antioxidant activities an antimicrobial activity using 2,2-diphenyl1-picrylhydrazyl (DPPH) and agar well diffusion method respectively. In addition, exract of Ficus carica prepared by soxlet apparatus and were partially purified by preparatory Thin Layer Chromatography (TLC). In conclusion, the results indicate antimicrobial activity of the extract which could be further explored for purification of antioxidant compounds.
\end{abstract}

Keywords: Ficus carica, Antioxidant, Free Radicals, Antimicrobial, DPPH, Well Diffusion Method

\section{Introduction}

For promoting the use of medicinal plants as useful sources of antioxidant and antimicrobial compounds, it is important to thoroughly investigate their composition and activity and thus validate their uses.

Thousands of plants are there, that are well known in traditional medicine system for their medicinal and therapeutic potentials worldwide. Similarly, Ficus carica is also one of the medicinally important plant that belongs to the mulberry tree (Moraceae) and also one of the oldest fruits in the world. Ficus carica is commonly known as Anjir [India], figs [UK], teen [Arabic]. Figs (Ficus carica Linn.) are cultivated for over 11,000 years according to literature survey and can almost certainly predate for human use. Figs are the earliest cultivated plants [1] and used in our traditional system of medicine for healing various diseases like, diabetes, ulcer, cancer, fever etc., [2]. Its strong antioxidant and biological properties are also known to diffuse the toxic free radical. It can also be used as a possible food additive or in nutraceutical and biophar, also used as a digestion promoter and a cure for ulcerative inflammation and eruption in Korea [3]. For the evaluation of the anti-pyretic effect of an ethanol extract of leaves of Ficus carica Linn, a study was carried out at normal body temperature and yeast-induced pyrexia, in albino rats [4].

Leaves of Ficus carica shows high degree antimicrobial activity of methanol extract against oral bacteria. The combination effects of $\mathrm{MeOH}$ extract with ampicillin or gentamicin are synergistic against oral bacteria [3]. The methanol extracts made from bark, fruits and leaves of F. carica consists strong antioxidant activity demonstrated by the four different methods including DPPH and ABTS+free radicals scavenging, PMS-NADH system superoxide radical scavenging and $\beta$-carotenelinoleic acid system. Psoralen and bergapten (5-methoxypsoralen) are two photoactive furanocoumarins reported in F. carica leaves. All but especially psoralen are used along with UV radiation in the treatment of skin diseases, such as skin depigmentation, mycosis fungoides, polymorphous dermatitis and eczema. Latex extracts of $F$. carica contain strong anti-angiogenic and anti-proliferative activities. It means that latex extract could be used as a potential agent for the prevention of angiogenesis in cancer and other chronic disorders [5]. Immunomodulatory effect of ethanolic extract of the leaves of Ficus carica (Moraceae) was investigated in mice, which shows promising immunostimulant properties [6].

Ficus carica latex also has been studied for its antimicrobial activity in this Methanolic, hexanoïc, chloroformic and ethyl acetate extracts of

properties against many bacteria and fungi [7]. Antimicrobial activity of methanol $(\mathrm{MeOH})$ extract of fig leaves against methicillin-resistant Staphylococcus aureus (MRSA) isolated in clinic and leaves could be employed as a natural antibacterial agent in MRSA infection care products [3]. Leaves contain bergapten, $4^{\prime}, 5^{\prime}$-dihydropsoralen, rutin, 24-methylene cycloartenol umbelliferone, marmesin, stigmasterol, $\beta$-sitosterol, ficusogenin, lupeol, psoralen $\psi$-taraxasterol ester and tyrosine moisture, protein, Umbelliferone tyrosin fat, beta-sitosterol, crude fiber, ash, $\mathrm{N}$-free extract Ficusin, pentosans, carotene on a dry weight basis [1-3,6,8-10] introduced significant hepatoprotective activity with the petroleum ether $\left(60-80^{\circ} \mathrm{C}\right)$ leaf extract of Ficus carica Linn. with rifampicin induced hepatic damage on rats [11]. Its pharmacological actions include antibacterial, antioxidant, antiinflammatory, vulnerary, antitumor, anticancer, antispasmodic, immunobalancing/immunoharmonizing, antidiabetic, antihelmintic, antiplatelet, hepatoprotective, hypocholesterolemic activity, Antispasmodic activity Haemostatic effect and antipyretic activities [12-18].

*Corresponding author: Javed Ahmad, Department of Biochemical Engineering and Food Technology, Harcourt Butler Technological Institute (HBTI), Kanpur, India, Tel: +91 9807121672; E-mail: Javedkkhaan@gmail.com

Received December 12, 2012; Accepted January 15, 2013; Published January 20,2013

Citation: Ahmad J, khan I, Khan S, Iqbal D (2013) Evaluation of Antioxidant and Antimicrobial Activity of Ficus Carica Leaves: an In Vitro Approach. J Plant Pathol Microb 4:157. doi:10.4172/2157-7471.1000157

Copyright: ( 2013 Ahmad J, et al. This is an open-access article distributed under the terms of the Creative Commons Attribution License, which permits unrestricted use, distribution, and reproduction in any medium, provided the original author and source are credited. 
Citation: Ahmad J, khan I, Khan S, Iqbal D (2013) Evaluation of Antioxidant and Antimicrobial Activity of Ficus Carica Leaves: an In Vitro Approach. J Plant Pathol Microb 4:157. doi:10.4172/2157-7471.1000157

\section{Material and Methods}

\section{Chemicals}

Methanol (merck india), Thin layer chromatography (TLC) plates, silicagel (merck india), DPPH (Merck india) peptone (Merck India), beef extract, agar, Nacl (Merck India). All other chemicals and reagents are of AR grade.

\section{Test microorganism}

Test microorganism which were used in this experiment are: Klebsiella pneumoniae, B. cereus, E. aerogens, B. substilus, S. epidermidus, at different concentration $(30,40,50,60 \mu \mathrm{g} / \mathrm{ml})$ concentration was used as a standard. All tested bacteria cultures were obtained and authenticated from Department of Bioscience, Integral University Lucknow, India.

\section{Plant material}

The fresh leaf of plants Ficus carica were collected from the wild sources herbal garden Pharmacy block integral university Lucknow, India, in the month of January and were authentified by Faculty of Pharmacy, Integral University, Lucknow, India.

The dried leaf powder (20 gm) of plant Ficus carica was extracted successively with $200 \mathrm{ml}$ each of methanol in a soxhlet extractor for 24 hrs. The solvent was evaporated at $30-35^{\circ} \mathrm{C}$. The methanolic extracts of F. carica yield a dark brownish solid residue weighing $2.44 \mathrm{gm}(12.2 \%$ $\mathrm{w} / \mathrm{w})$.

\section{Antioxidant assay}

Each sample was dissolved in $95 \%$ methanol at a concentration $1 \mu \mathrm{g} / \mathrm{ml}$ and then diluted to prepare the series concentrations for antioxidant assays. Reference chemicals were used for comparison in all assays, all steps done in triplicate. DPPH radical scavenging activity assay: The DPPH assay was done according to the method of Brand-Williams, Cuvelier, and Berset with some modifications [19]. The stock solution was prepared by dissolving $24 \mathrm{mg}$ DPPH with $100 \mathrm{ml}$ methanol and then stored at $20^{\circ} \mathrm{C}$ until needed. The working solution was obtained by diluting DPPH solution with methanol to obtain an absorbance of about $0.980( \pm 0.02)$ at $517 \mathrm{~nm}$ using the spectrophotometer. A $3 \mathrm{ml}$ aliquot of this solution was mixed with $100 \mathrm{ml}$ of the fractions at varying concentrations $(25-250 \mu \mathrm{g} / \mathrm{ml})$. The solution in the test tubes were shaken well and incubated in the dark for $15 \mathrm{~min}$ at room temperature. Then the absorbance was taken at $517 \mathrm{~nm}$. The scavenging activity was estimated based on the percentage of DPPH radical scavenged using the following equation: Scavenging effect (OD of control absorbanceOD of sample absorbance)/OD of control absorbance $\times 100$ : EC50 value is the effective concentration that could scavenge $50 \%$ of the DPPH radicals. Ascorbic acid was used as standard.

\section{Partial purification of the extract}

The methanolic extracts of the plant were subjected to TLC $(0.25$ $\mathrm{mm}, 20 \times 20 \mathrm{~cm}, \mathrm{SiO}_{2} \mathrm{GF} 254$, Merck India) and developed in a solvent system of methanol:chloroform (4:1) of $150 \mathrm{ml}$. The TLC of F. carica extracts showed 2 different bands, respectively [20,21].

\section{Agar well diffusion method}

Find the extracts from the plants for studying their antibacterial activity. A loop full of bacterial strain was inoculated in of Nutrient broth in a conical flask and incubated for $72 \mathrm{hrs}$. After solidification $0.25 \mathrm{ml}$ of test strains were inoculated in the media separately and cared for proper homogenization. The experiment was performed under strict aseptic conditions. After the medium solidified, a well was made in the plates with sterile borer $(5 \mathrm{~mm})$. Then extract compound was introduced into the well and plates were incubated at $37^{\circ} \mathrm{C}$ for about overnight. All samples were tested in triplicates. Microbial growth was determined by measuring the diameter of zone of inhibition.

\section{Results and Discussion}

The scavenging the stable DPPH radical is a widely used method to evaluate the free radical scavenging ability of various samples, including plant extracts. The measured DPPH radical scavenging activity is shown in table 1 and figure 1 . The $F$. carica leaves extract scavenging antioxidant activity was significantly increased with increasing concentration of the extract. The effect of antioxidants on DPPH is thought to be due to their hydrogen donating ability. Although the DPPH radical scavenging abilities of the extracts were significantly lower than those of ascorbic acid, it was evident that the extracts did show some proton-donating ability and could serve as free radical inhibitors or scavengers, acting possibly as primary antioxidants. The quality of the antioxidants in the extracts was determined by the percent inhibition values shown in table 2 and figure 2. Although the percent inhibition values of F. carica leaves extract were not much greater than the reference antioxidant. Lack of hydrogen donor bioactive constituents in the extract, slow rate of the reaction between DPPH and the substrate molecules resulting in low readings for antioxidant activity probably might explain the low DPPH antioxidant activity of the F. carica leaves extract [22-25].

\begin{tabular}{|l|l|l|}
\hline Sample concentration $(\boldsymbol{\mu g} / \mathrm{ml})$ & Ascorbic acid(OD) & F. carica (leaves) $(\mathrm{OD})$ \\
\hline $25 \mu \mathrm{g} / \mathrm{ml}$ & $1.269 \pm .001$ & $1.285 \pm 0.15$ \\
\hline $50 \mu \mathrm{g} / \mathrm{ml}$ & $1.212 \pm .005$ & $1.225 \pm 0.18$ \\
\hline $100 \mu \mathrm{g} / \mathrm{ml}$ & $1.048 \pm .008$ & $1.10 \pm 0.14$ \\
\hline $150 \mu \mathrm{g} / \mathrm{ml}$ & $0.884 \pm .009$ & $1.04 \pm 0.13$ \\
\hline $250 \mu \mathrm{g} / \mathrm{ml}$ & $0.571 \pm .015$ & $1.00 \pm 0.09$ \\
\hline
\end{tabular}

Table 1: Absorbance of $F$. carica methanolic leaf extract at various concentrations in DPPH mediated free radical scavenging system.

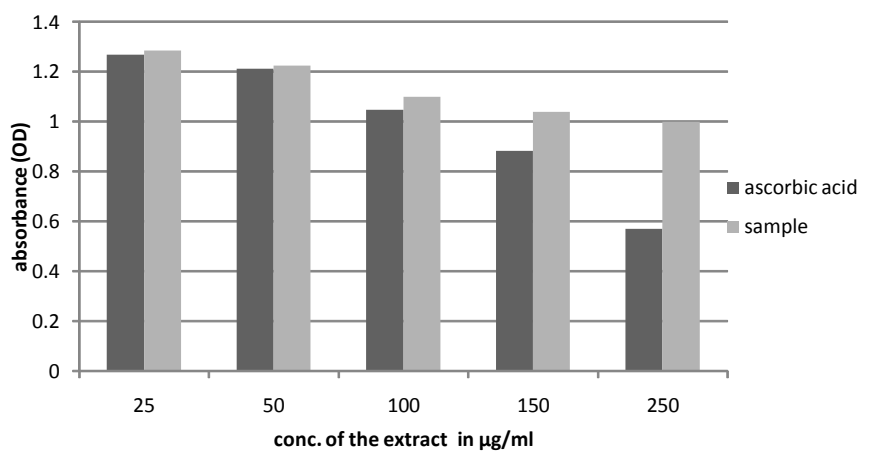

Figure 1: Absorbance of F. carica metabolic leaf extract at various concentrations in DPPH mediated free radical scavenging system.

\begin{tabular}{|l|l|l|}
\hline $\begin{array}{l}\text { Sample } \\
\text { concentration }(\boldsymbol{\mu g} / \mathbf{m l})\end{array}$ & $\begin{array}{l}\text { Ascorbic Acid } \\
(\% \text { scavenging inhibition) }\end{array}$ & $\begin{array}{l}\text { F. carica (leaves) } \\
(\% \text { scavenging inhibition) }\end{array}$ \\
\hline 25 & 7.1 & 0.1822 \\
\hline 50 & 13.1 & 1.522 \\
\hline 100 & 28.3 & 4.111 \\
\hline 150 & 40.3 & 8.101 \\
\hline 250 & 60.4 & 10.222 \\
\hline
\end{tabular}

Table 2: Percent Inhibition of DPPH mediated free radical generation by $\mathrm{F}$ carica methanolic leaf extract at various concentrations. 
Citation: Ahmad J, khan I, Khan S, Iqbal D (2013) Evaluation of Antioxidant and Antimicrobial Activity of Ficus Carica Leaves: an In Vitro Approach. J Plant Pathol Microb 4:157. doi:10.4172/2157-7471.1000157

Page 3 of 4

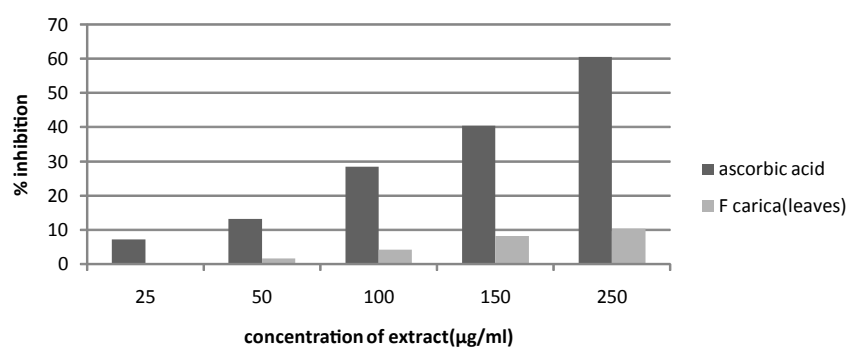

Figure 2: Percent Inhibition of DPPH mediated free radical generation by $F$ carica methanolic leaf extract at various concentrations.

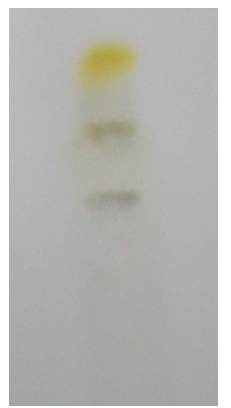

Figure 3a: Thin layer Chromatography.

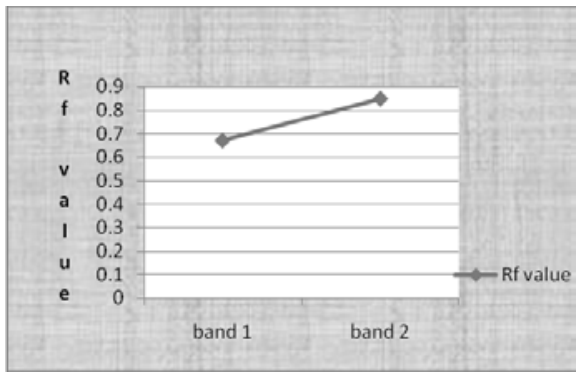

Figure 3b: Rf Values

\section{Thin layer chromatograph (TLC)}

The TLC of methanolic extract for F. carica plant is shown in figure $3 \mathrm{a}$ and $3 \mathrm{~b}$ with their $\mathrm{R}_{\mathrm{F}}$ values. Based on solvent system used for TLC, silica gel column will be executed. There are two clear band was found. From the figure it is evident that there are many compounds or components that are responsible for the antioxidant activity. Hence, further investigations are required to isolate, purify and characterized those compounds which are responsible for this antioxidant activity.

\section{Antimicrobial activity}

Antimicrobial activity was determined by using agar well diffusion assay. Our results indicated a potent antioxidant and antimicrobial activity of methanolic leaf extract of $F$. carica. In the present study methanolic extracts of plant have been tested against resistant bacteria. The antimicrobial activity of the extracts and their potency was quantitatively assessed by the presence or absence of inhibition zone and zone diameter (Table 3 ).

The results of antimicrobial activity of F. carica was encouraging and that the plant extract showed significant antimicrobial activity

\begin{tabular}{|l|l|l|l|l|l|}
\hline \multirow{2}{*}{ S.No. } & Strains & \multicolumn{4}{l|}{ Concentrations } \\
\cline { 3 - 6 } & & $30 \mu \mathrm{g} / \mathrm{ml}$ & $40 \mu \mathrm{g} / \mathrm{ml}$ & $50 \mu \mathrm{g} / \mathrm{ml}$ & $60 \mu \mathrm{g} / \mathrm{ml}$ \\
\hline $\mathbf{1}$ & K.pneumoniae & $1.2 \mathrm{~cm}$ & $1.25 \mathrm{~cm}$ & $1.3 \mathrm{~cm}$ & $1.35 \mathrm{~cm}$ \\
\hline $\mathbf{2}$ & B.cereus & $1.15 \mathrm{~cm}$ & $1.20 \mathrm{~cm}$ & $1.25 \mathrm{~cm}$ & $1.3 \mathrm{~cm}$ \\
\hline $\mathbf{3}$ & B.subtilis & $1.1 \mathrm{~cm}$ & $1.25 \mathrm{~cm}$ & $1.3 \mathrm{~cm}$ & $1.35 \mathrm{~cm}$ \\
\hline $\mathbf{4}$ & S.epidermidis & $1.2 \mathrm{~cm}$ & $1.25 \mathrm{~cm}$ & $1.30 \mathrm{~cm}$ & $1.40 \mathrm{~cm}$ \\
\hline $\mathbf{5}$ & E.aerogens & $1.05 \mathrm{~cm}$ & $1.1 \mathrm{~cm}$ & $1.2 \mathrm{~cm}$ & $1.25 \mathrm{~cm}$ \\
\hline
\end{tabular}

Table 3: Zone inhibition by F. carica.

\begin{tabular}{|l|l|l|l|}
\hline S.No. & Strains & MIC & MBC \\
\hline $\mathbf{1}$ & K. pneumoniae & $7 \mu \mathrm{g} / \mathrm{ml}$ & $11 \mu \mathrm{g} / \mathrm{ml}$ \\
\hline $\mathbf{2}$ & B. cereus & $3 \mu \mathrm{g} / \mathrm{ml}$ & $6 \mu \mathrm{g} / \mathrm{ml}$ \\
\hline $\mathbf{3}$ & S. epdermidis & $4 \mu \mathrm{g} / \mathrm{ml}$ & $7 \mu \mathrm{g} / \mathrm{ml}$ \\
\hline $\mathbf{4}$ & B. subtilis & $6 \mu \mathrm{g} / \mathrm{ml}$ & $11 \mu \mathrm{g} / \mathrm{ml}$ \\
\hline $\mathbf{5}$ & E. aerogens & $3.5 \mu \mathrm{g} / \mathrm{ml}$ & $8 \mu \mathrm{g} / \mathrm{ml}$ \\
\hline
\end{tabular}

Table 4: $\mathrm{MIC} / \mathrm{MBC}$ of various bacterial strains by $F$. carica.

against different bacterial strains. Antimicrobial activity of methanolic extract of F. carica against five bacterial strain B. cereus, E. aerogens, K. pneumoniae, B. substilis, S. epidermidis at different concentration $(30,40,50,60 \mu \mathrm{g} / \mathrm{ml})$ was found in the following decreasing order $S$. epidermidis $>$ K. pneumoniae $>B$. subtilis $>B$. cereus $>$ E. aerogens (Table $3)$.

Determination of antibacterial activity by agar well diffusion assay showed that methanolic extract of $F$. carica leaves exhibited the antibacterial effect against pathogenic as well as non-pathogenic test bacteria. Significant effect on growth inhibition of gram positive and gram negative bacteria was also noticed. It was noted that among all tested organisms: the gram positive bacterial strain S. epidermidis registered maximum susceptibility to the methanolic extract at $60 \mu \mathrm{g} /$ $\mathrm{ml}$ of the entire $F$. carica leaves, with the maximum inhibitory zone of $1.40 \mathrm{~cm}$. MIC/MBC of various bacterial strains by $F$. carica are shown in table 4 .

Phytochemical analysis of the extract denoted the presence of flavonoids and phenols. The presence of these compounds was detected by Thin Layer Chromatography. The obtained results might be considered sufficient to further studies for the isolation and identification of the active principles and to evaluate of possible synergism among extract components for their antioxidant and antimicrobial activity.

\section{Conclusion}

In conclusion, Ficus species are rich source of naturally occurring antioxidant and antimicrobial activity. Its compound play a vital role in preventing innumerable health disorders related to oxidative stress including cardiovascular diseases, neurodegenerative diseases and cancer. Our results indicated a significant increase in antioxidant activity of Ficus carica leaves extract. In addition, the extract also showed potent antimicrobial activity with all the bacterial strains with maximum inhibition against $S$. epidermidis. These results encourage the researchers to do further in vitro and in vivo research that will explore the role of bioactive constituents responsible for these activities. Hence, further studies are needed to evaluate the antioxidant activity and antimicrobial activity of their partially purified fractions. Further studies are also needed at molecular level.

\section{References}

1. Kislev ME, Hartmann A, Bar-Yosef O (2006) Early domesticated fig in the Jordan valley. Science 312: 1372-1374. 
Citation: Ahmad J, khan I, Khan S, Iqbal D (2013) Evaluation of Antioxidant and Antimicrobial Activity of Ficus Carica Leaves: an In Vitro Approach. J Plant Pathol Microb 4:157. doi:10.4172/2157-7471.1000157

2. Sirisha N, Sreenivasulu M, Sangeeta K, Madhusudhana Chetty C (2010) Antioxidant properties of Ficus species-A Review. Int J PharmTech Res 2: 2174-2182.

3. Jeong MR, Kim HY, Cha JD (2009) Antimicrobial activity of methanol extract from Ficus carica leaves against oral bacteria. J Bacteriol Virol 39: 97-102

4. Patil VV, Bhangale SC, Patil VR (2010) Studies on immunomodulatory activity of Ficus carica. Int J Pharm Pharm Sci 2: 97-99.

5. Mostafaie A, Mansouri K, Norooznezhad AH, Mohammadi-Motlagh HR (2011) Anti-angiogenic activity of Ficus carica latex extract on human umbilical vein endothelial cells. Cell J 12: 525-528.

6. Patil VV, Bhangale SC, Patil VR (2010) Evaluation of anti-pyretic potential of Ficus carica leaves. Int J Pharm Sci Rev Res 2: 48-50.

7. Aref HL, Salah KB, Chaumont JP, Fekih A, Aouni M, et al. (2010) In vitro antimicrobial activity of four Ficus carica latex fractions against resistant human pathogens (antimicrobial activity of Ficus carica latex). Pak J Pharm Sci 23 : $53-58$.

8. Young-Soo L, Cha JD (2010) Synergistic antibacterial activity of fig (Ficus carica) leaves extract against clinical isolates of Methicillin-resistant Staphylococcus aureus. Kor J Microbiol Biotechnol 38: 405-413.

9. Li C, Bu PB, Yue DK, Sun YF (2006) Chemical constituents from roots of Ficus hirta. Zhongguo Zhong Yao Za Zhi 31: 131-133.

10. Patil VV, Patil VR (2011) Evaluation of anti-inflammatory activity of Ficus carica Linn. leaves. Indian Journal of Natural Product and Resources 2: 151-155.

11. Gond NY, Khadabadi SS (2008) Hepatoprotective activity of Ficus carica lea extract on rifampicin-induced hepatic damage in rats. Indian J Pharm Sci 70 : 364-366

12. Chang MS, Yang YC, Kuo YC, Kuo YH, chang C, et al. (2005) Furocoumarin glycosides from the leaves of Ficus ruficaulis Merr. var. antaoensis. J Nat Prod 68: $11-13$.

13. Perez C, Canal JR, Torres MD (2003) Experimental diabetes treated with Ficus carica extract: effect on oxidative stress parameters. Acta Diabetol 40: 3-8.

14. Joseph B, Raj SJ (2011) Pharmacognostic and phytochemical properties of Ficus carica Linn-An overview. Int J PharmTech Res 3: 8-12.
15. Rubnov S, Kashman Y, Rabinowitz R, Schlesinger M, Mechoulam R (2001) Suppessors of cancer cell proliferation from fig (Ficus Carica Linn.) resin isolation and structure elucidation. J Nat Prod 64: 993-996.

16. Saeed MA, Sabir AW (2002) Irritant potential of triterpenoids from Ficus carica Linn. leaves Fitoterapia. J Nat Prod 73: 417-420.

17. Vinson JA (1999) The functional food properties of figs. Cereal Foods World 44: 82-87.

18. Wu PL, Rao KV, Su CH, Kuoh CS, Wu TS (2002) Phenanthroindolizidine alkaloids and their cytotoxicity from the leaves of Ficus septica. Heterocycles 57: 2401-2408.

19. Bondet V, Brand-Williams W, Berset C (1997) Kinetics and mechanisms of antioxidant activity using the DPPH free radical method. LWT-Food Sci Technol 30: 609-615.

20. Canal JR, Torres MD, Romero A, Perez C (2002) A chloroform extract obtained from a decoction of Ficus carica leaves, improve the chlosterolaemia of rats with streptozocin-induced diabetes. Acta Physiol Hung 87: 71-76.

21. Innocenti G, Bettero A, Caporale G (1982) Determination of the coumarinic constituents of Ficus carica Linn. leaves by HPLC. II Farmaco Edizione Scientifica 37: 475-485

22. Ahmed F, Khan RA, Rasheed S (1992) Study of analgesic and anti-inflammatory activity from plant extracts of Lactuca scariola and Artemisla absinthium. J Islamic Acad Sci 5: 111-114.

23. Richter G, Schwarz HP, Dorner F, Peter L (2002) Activation and inactivation of human factor $\mathrm{X}$ by proteases derived from Ficus carica Linn. British Journal of Haematology 119: 1042-1051.

24. Stepek G, Buttle DJ, Duce IR, Lowe A, Behnke JM (2005) Assessmen of the anthelmintic effect of natural plant cysteine proteinases against the gastrointestinal nematode, Heligmosomoides polygyrus, in vitro. Parasitology 130: 203-211.

25. Gilani AH, Mehmood MH, Janbaz KH, Khan AU, Saeed SA (2008) Ethnopharmacological studies on antispasmodic and antiplatelet activities of Ficus carica. J Ethnopharmacol 119: 1-5. 